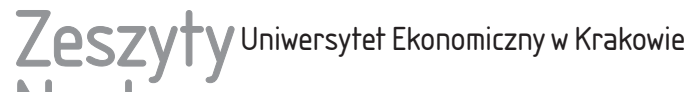 Naukowe
}

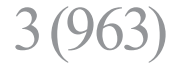

ISSN 1898-6447

Zesz. Nauk. UEK, 2017; 3(963): 123-139

DOI: 10.15678/ZNUEK.2017.0963.0308

\section{Magdalena Jelonek}

\section{Młodzi na wsi i w mieście - jakość zatrudnienia jako wymiar zróżnicowania szans zawodowych osób młodych*}

\section{Streszczenie}

Celem artykułu jest znalezienie odpowiedzi na pytanie o różnice w jakości zatrudnienia osób młodych mieszkających na wsi i w mieście. Przyjęto tezę, że zasadnicza różnica pomiędzy mieszkańcami miast i wsi widoczna jest nie tyle w samym prawdopodobieństwie posiadania zatrudnienia, ile w szansie na pracę wysokiej jakości, przyjmując, że jakość ta została scharakteryzowana zgodnie z konwencją OECD w trzech wymiarach, takich jak: poziom wynagrodzenia, stabilność zatrudnienia oraz jakość otoczenia zawodowego. Aby zweryfikować powyższą tezę, posłużono się danymi sondażowymi zgromadzonymi w ramach projektu Bilans Kapitału Ludzkiego w Polsce. Udowodniono, że największe różnice pomiędzy mieszkańcami miast i wsi wiążą się z większą szansą na awans ekonomiczny mieszkańców miast. Równocześnie zidentyfikowano dwa kluczowe czynniki, które moderują relacje między miejscem zamieszkania a jakością zatrudnienia, takie jak region (z silnymi lub słabymi ośrodkami miejskimi) oraz poziom wykształcenia badanych (wyższy i niższy).

Słowa kluczowe: jakość zatrudnienia, ludzie młodzi, szanse zawodowe, miasto, wieś, rynek pracy.

Klasyfikacja JEL: J70.

Magdalena Jelonek, Uniwersytet Ekonomiczny w Krakowie, Wydział Gospodarki i Administracji Publicznej, Katedra Socjologii, ul. Rakowicka 27, 31-510 Kraków, e-mail: magdalena.jelonek@uek. krakow.pl

* Artykuł powstał w ramach badań statutowych Katedry Socjologii finansowanych ze środków własnych przez Uniwersytet Ekonomiczny w Krakowie. 


\section{Wprowadzenie}

Sytuacja zawodowa młodych pracowników kształtowana jest przez szereg czynników o charakterze wewnętrznym i zewnętrznym. W analizach poświęconych przechodzeniu osób młodych ${ }^{1} \mathrm{z}$ systemu edukacji na rynek pracy (school-to-work transition) bierze się zazwyczaj pod uwagę trzy grupy czynników: czynniki indywidualne pozwalające na ocenę poziomu merytokratyczności społeczeństwa (np. wykształcenie) ${ }^{2}$, wpływ systemu edukacji na płynność tego przejścia oraz wpływ czynników instytucjonalnych związanych z rynkiem pracy [Domański i in. 2012].

W niniejszym artykule skupiono się na pierwszej grupie czynników, tj. czynnikach o charakterze indywidualnym, takich jak: pochodzenie społeczne, wykształcenie, kapitał kulturowy czy płeć. Najogólniej ujmując, są to wszelkiego rodzaju charakterystyki jednostki, które samodzielnie lub wespół z innymi cechami wpływają na jej szanse zawodowe.

Spośród czynników indywidualnych wybrany został jeden, tj. miejsce zamieszkania, powszechnie wskazywane jako jedna z najważniejszych determinant szans rynkowych osób młodych. Większość opracowań naukowych dowodzi, że te osoby, które mieszkają w ośrodkach miejskich, mają przeciętnie większe szanse na posiadanie pracy niż mieszkańcy ośrodków pozamiejskich ${ }^{3}$ (por. [Jelonek, Kasparek i Magierowski 2015, Nurzyńska i Poczta 2014]). Jednakże w artykule pokazano, że nie tylko szanse zdobycia jakiejkolwiek pracy przez mieszkańców miast są większe, ale też z wyższym prawdopodobieństwem zdobędą oni pracę wyższej jakości. Jakość zatrudnienia została scharakteryzowana zgodnie z konwencją OECD [OECD Employment... 2014] w podziale na trzy wymiary, tj. poziom wynagrodzenia, stabilność zatrudnienia oraz jakość otoczenia zawodowego.

Analizy zaprezentowane $\mathrm{w}$ artykule zostały przeprowadzone na podstawie danych zgromadzonych w ramach projektu Bilans Kapitału Ludzkiego w Polsce (BKL). Posłużono się w tym celu bazą danych z reprezentatywnych badań ludności przeprowadzonych w latach 2010-2014.

W artykule na wstępie scharakteryzowano sytuację zawodową osób młodych mieszkających w miastach i na wsiach, biorąc pod uwagę podstawowy wskaźnik służący do jej opisu, tj. stopę bezrobocia według Badania Aktywności Ekono-

${ }^{1}$ Za osoby młode uważa się w tym artykule osoby do 30 roku życia.

2 Moderuje szanse posiadania odpowiedniej jakości pracy [Harmon i Walker 2000, Dearden i in. 2002, O’Leary i Sloane 2011, Jelonek i Szklarczyk 2012], a także gwarantuje mniejsze straty w momentach spowolnienia gospodarczego [Jelonek i Mazur 2014].

${ }^{3} \mathrm{~W}$ niniejszym artykule stopa zwrotu jest definiowana w sposób jakościowy, odnosząc się jedynie częściowo do klasycznego w ekonomii podejścia monetarnego (np. [Mincer 1974, Lauer i Steiner 2000, Investment... 2002, Psacharopoulos i Patrinos 2002]). 
micznej Ludności (BAEL). Następnie dokonano analizy jakości pracy wykonywanej przez mieszkańców wsi i miast. W podsumowaniu zawarto interpretację danych empirycznych na temat perspektyw zawodowych osób młodych mieszkających w miastach i na wsi.

\section{Ogólna sytuacja zawodowa osób młodych a miejsce ich zamieszkania}

Przed przystąpieniem do szczegółowej charakterystyki jakości zatrudnienia ludzi młodych mieszkających na wsi i w mieście zostaną przedstawione ogólne wartości wskaźników w najprostszy sposób opisujące sytuację zawodową absolwentów. Nie wdając się w szczegóły, widoczna jest niewielka, jednak istotna statystycznie różnica pomiędzy mieszkańcami miast i wsi - pierwszych charakteryzuje niższe prawdopodobieństwo bycia bezrobotnymi. Szanse zawodowe określa także inna zmienna geograficzna, tj. region zamieszkania, niemniej jednak pomimo odmiennych sytuacji na rynkach regionalnych często obserwuje się opisaną powyżej korzyść bycia mieszkańcem miasta ${ }^{4}$ (rys. 1).

Autorzy publikacji naukowych i raportów dotyczących rynku pracy różnie tłumaczą przedstawioną zależność. Zwracają oni uwagę zarówno na działanie czynników zewnętrznych, jak np. mniejsza elastyczność rynków pracy na terenach pozamiejskich [Stan istruktura... 2015, Mlonek 2006], jak i wewnętrznych (niekorzystna struktura wykształcenia czy braki kompetencyjne w przypadku mieszkańców ośrodków wiejskich) [Nurzyńska i Poczta 2014].

Prawdopodobieństwo posiadania pracy czy też bycia bezrobotnym jednak nie różnicuje jednoznacznie mieszkańców miast i wsi - zaobserwować można pewne odmienności regionalne. Wskazują na to m.in. dane znajdujące się w tabeli 1. Jeśli korzyść z zamieszkania w mieście byłaby regułą, wtedy w każdym regionie występowałaby dodatnia różnica w odsetku bezrobotnych na wsi i w mieście. $\mathrm{W}$ istocie tak jednak nie jest. W niektórych województwach obserwuje się znacznie lepszą sytuację zawodową mieszkańców ośrodków miejskich (warmińsko-mazurskie, mazowieckie, kujawsko-pomorskie), w innych odsetek osób bez pracy okazuje

${ }^{4}$ Ludność zamieszkałą na wsi można zaklasyfikować do dwóch grup: tych, których praca jest związana z gospodarstwem rolnym oraz pracowników spoza sektora rolnego. Ministerstwo Pracy i Polityki Społecznej wskazuje na gorszą - w świetle oficjalnych wskaźników - sytuację zawodową w drugiej grupie [Stan i struktura... 2015, s. 1]. W grupie pierwszej problemem nie jest bezrobocie jawne, lecz ukryte. Równocześnie zauważyć należy, że osoby młode częściej będą szukać pracy poza rolnictwem, a zatem w ich przypadku szansa znalezienia się w grupie ryzyka będzie podwójna. Dodać należy, że sytuacja młodych osób zamieszkujących tereny znajdujące się względnie blisko dużych ośrodków miejskich będzie inna niż sytuacja tych, dla których dojazd do pracy w mieście jest nieopłacalny. 
się większy w miastach (świętokrzyskie, podlaskie, wielkopolskie). Można przedstawić wiele potencjalnych przyczyn przedstawionych różnic regionalnych, zakładając, że większość z nich wynika z zastosowania wskaźnika bezrobocia BAEL. Odmienności regionalne mogą świadczyć o częstszym występowaniu bezrobocia ukrytego na wsiach (gdy stopa bezrobocia okazuje się większa w mieście), czy o bezrobociu lokalnym (obejmującym tylko część regionu, zarówno miasta, jak i wsie). Zazwyczaj jednak, gdy kondycja gospodarcza regionu jest słabsza, obserwuje się większą różnicę w bezrobociu mieszkańców miast i wsi, naturalnie na niekorzyść tych drugich.

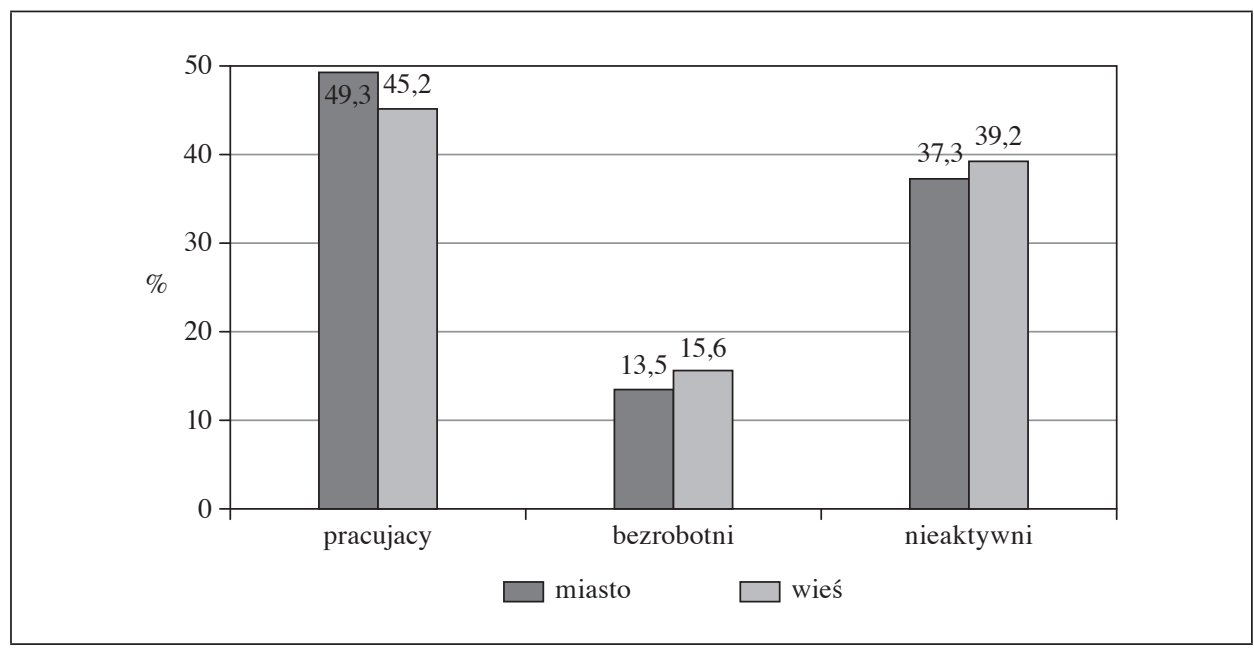

Uwaga: do obliczeń przyjęto definicję osoby bezrobotnej zgodnie z BAEL ${ }^{5}$.

Rys. 1. Procent osób pracujących, bezrobotnych i nieaktywnych zawodowo w badanych grupach (procent ważnych odpowiedzi; liczba ważnych odpowiedzi: miasto - 16198 , wieś - 11062)

Źródło: opracowanie własne na podstawie danych BKL 2010-2014.

Przedstawione różnice regionalne nie są jednoznacznie interpretowalne, dlatego należy poddać analizie kolejny czynnik, który można uznać za element zróżnicowania szans zawodowych mieszkańców miast i wsi, a mianowicie jakość zatrudnienia.

${ }^{5}$ Zgodnie z definicją GUS (przyjmowaną w BAEL) osoba bezrobotna to osoba: 1) między 15 a 74 rokiem życia, 2) niepracująca w tygodniu, w którym przeprowadzano badanie, 3) aktywnie poszukująca pracy (w ciągu ostatnich 4 tygodni podjęła konkretne działania w celu podjęcia pracy, 4) gotowa podjąć pracę w ciągu dwóch tygodni po badaniu). 
Tabela 1. Bezrobocie na wsi i w mieście w układzie województw

\begin{tabular}{|c|c|c|c|c|}
\hline Województwo & Miasto/wieś & $\begin{array}{l}\text { Bezrobotni } \\
\quad(\mathrm{w} \%)\end{array}$ & $\begin{array}{l}\text { Różnica bezro- } \\
\text { bocia między } \\
\text { miastem a wsią } \\
\text { (w pkt proc.) }\end{array}$ & $N$ \\
\hline \multirow{2}{*}{ Dolnośląskie } & miasto & 13,9 & \multirow{2}{*}{1,8} & 1413 \\
\hline & wieś & 15,6 & & 645 \\
\hline \multirow{2}{*}{ Kujawsko-pomorskie } & miasto & 13,5 & \multirow{2}{*}{4,1} & 892 \\
\hline & wieś & 17,6 & & 627 \\
\hline \multirow{2}{*}{ Lubelskie } & miasto & 16,3 & \multirow{2}{*}{1,7} & 751 \\
\hline & wieś & 17,9 & & 835 \\
\hline \multirow{2}{*}{ Lubuskie } & miasto & 16,7 & \multirow{2}{*}{$-0,9$} & 464 \\
\hline & wieś & 15,7 & & 283 \\
\hline \multirow{2}{*}{ Łódzkie } & miasto & 11,9 & \multirow{2}{*}{2,0} & 1086 \\
\hline & wieś & 14,0 & & 617 \\
\hline \multirow{2}{*}{ Małopolskie } & miasto & 14,3 & \multirow{2}{*}{1,7} & 1187 \\
\hline & wieś & 16,0 & & 1290 \\
\hline \multirow{2}{*}{ Mazowieckie } & miasto & 9,9 & \multirow{2}{*}{6,0} & 2115 \\
\hline & wieś & 16,0 & & 1332 \\
\hline \multirow{2}{*}{ Opolskie } & miasto & 9,9 & \multirow{2}{*}{1,9} & 375 \\
\hline & wieś & 11,8 & & 351 \\
\hline \multirow{2}{*}{ Podkarpackie } & miasto & 19,1 & \multirow{2}{*}{2,6} & 666 \\
\hline & wieś & 21,7 & & 926 \\
\hline \multirow{2}{*}{ Podlaskie } & miasto & 17,3 & \multirow{2}{*}{$-2,7$} & 570 \\
\hline & wieś & 14,6 & & 336 \\
\hline \multirow{2}{*}{ Pomorskie } & miasto & 10,8 & \multirow{2}{*}{2,9} & 1034 \\
\hline & wieś & 13,7 & & 599 \\
\hline \multirow{2}{*}{ Śląskie } & miasto & 13,3 & \multirow{2}{*}{$-1,4$} & 2393 \\
\hline & wieś & 11,9 & & 722 \\
\hline \multirow{2}{*}{ Świętokrzyskie } & miasto & 17,4 & \multirow{2}{*}{$-4,5$} & 399 \\
\hline & wieś & 13,0 & & 501 \\
\hline \multirow{2}{*}{ Warmińsko-mazurskie } & miasto & 16,0 & \multirow{2}{*}{6,3} & 650 \\
\hline & wieś & 22,3 & & 452 \\
\hline \multirow{2}{*}{ Wielkopolskie } & miasto & 12,4 & \multirow{2}{*}{$-1,8$} & 1369 \\
\hline & wieś & 10,6 & & 1145 \\
\hline 7 Thedionomole & miasto & 14,4 & 2 & 835 \\
\hline 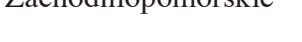 & wieś & 17,5 & $J, 1$ & 402 \\
\hline
\end{tabular}

Źródło: opracowanie własne na podstawie danych BKL 2010-2014. 


\section{Jakość zatrudnienia w mieście i na wsi}

Według M. Olędzkiego [1981, s. 26] jakość pracy można określić „jako wartość społeczną, wynikającą z jednostkowej, scalonej satysfakcji materialnej, uwarunkowanej kwalifikacjami i predyspozycjami do dobrej pracy oraz osiąganymi efektami pracy, ale również warunkami materialnymi i społecznymi środowiska pracy, dostosowanymi do współczesnych społecznych standardów jakości pracy”. Zdaniem autora, na jakość zatrudnienia wskazywać będą zarówno elementy obiektywne, takie jak: warunki materialne i społeczne środowiska pracy, jak również czynniki subiektywne, związane z poczuciem zadowolenia z wykonywanych zadań. Wśród czynników natury obiektywnej wymienia się najczęściej takie czynniki, jak: materialne warunki pracy, bezpieczeństwo podczas wykonywania zadań zawodowych, pewność zatrudnienia, atmosferę, model komunikacji w zespole, strategię inwestowania w zasoby ludzkie, możliwość godzenia ról zawodowych z rodzinnymi czy styl zarządzania kierownictwa, w tym partycypacja w podejmowaniu decyzji [Jakość życia... 2013, Handbook... 2015].

Podobną perspektywę, tym razem w skali makro, przyjęto w raporcie OECD z 2014 r. pt. OECD Employment Outlook 2014, oceniając kraje pod względem: wysokości zarobków, nierówności dochodowych, ryzyka utraty pracy, świadczeń dla bezrobotnych i komfortu pracy. Polska zajęła w rankingu krajów europejskich jedno z ostatnich miejsc, trafiając do trzeciej grupy, gdzie oprócz niej znajdują się m.in.: Turcja, Grecja i Słowacja (grupa, w której kraje miały niską punktację w minimum dwóch z trzech badanych aspektów i w żadnej z kategorii nie radziły sobie dobrze) - por. [OECD Employment... 2014].

Obecnie zostanie scharakteryzowania jakość pracy (w podobny sposób jak to przedstawia OECD), tj.: poziom wynagrodzenia, stabilność zatrudnienia oraz jakość otoczenia zawodowego mieszkańców miast i wsi. Chcąc uwzględnić intensywność wykonywanej pracy, obliczono poziom wynagrodzenia za godzinę pracy (przeciętna cena wykonywanej godziny pracy). Ocenę stabilności zatrudnienia ograniczono do charakterystyki dwóch subiektywnych wskaźników stabilności, tj. zadowolenia z pewności zatrudnienia oraz prognoz odnośnie do rozwoju kariery zawodowej w najbliższych dwunastu miesiącach. Podobnie w przypadku jakości otoczenia zawodowego posłużono się subiektywną oceną poziomu zadowolenia z warunków wykonywania pracy, możliwości awansu oraz możliwości rozwoju osobistego i szkoleń ${ }^{6}$.

${ }^{6} \mathrm{~W}$ przypadku oceny stabilności zatrudnienia posłużono się dwoma pytaniami o następującej treści: 1) Zadowolenie z pracy można rozpatrywać pod kilkoma względami. Proszę powiedzieć, jak bardzo jest Pan/Pani zadowolony/zadowolona bądź niezadowolony/niezadowolona z pewności zatrudnienia (skala 5-punktowa); 2) Jak się Panu/Pani wydaje, czy w ciągu najbliższych 12 miesięcy: pozostanie Pan/Pani na tym samym stanowisku, przejdzie na równorzędne stanowisko, awansuje Pan/Pani czy też przestanie Pan/Pani pracować w tym zakładzie. 


\section{Materialne warunki pracy}

W części tej w analizach uwzględniono zatrudnionych mieszkańców miast i wsi, pominięto zatem osoby prowadzące gospodarstwa rolne. Najprostszym i zarazem najczęściej stosowanym wskaźnikiem jakości zatrudnienia są zarobki [Dearden, Reed i Van Reenen 2006, Handbook... 2015]. Jest to równocześnie element różnicujący młodych mieszkańców miast i wsi zarówno w ujęciu ogólnym, jak i przy kontroli różnic regionalnych ${ }^{7}$.

O ile dane zagregowane dla całej Polski nie wskazują na dużą różnicę w średnich zarobkach ludzi młodych z miast i wsi, to jednak różnica ta jest istotna statystycznie, a średnie zarobki osób z miast są przeciętnie większe o około 200 zł netto. Analiza przeprowadzona na poziomie województw ukazuje dodatkowe wzory nierówności. Największą przepaść w przeciętnych zarobkach można zaobserwować w przypadku takich województw, jak: dolnośląskie (około 400 zł), lubuskie (około $300 \mathrm{zł}$ ), mazowieckie (500 zł), zachodniopomorskie (300 zł). Jednak tym, co w największym stopniu odróżnia wsie od miast nie jest pensja przeciętna osób młodych, ale szansa na uzyskanie przez nich pensji bardzo wysokiej (szansa ta jest różna w poszczególnych regionach). Różnica w wartości wyznaczającej dolną granicę dochodów 5\% najlepiej zarabiających mieszkańców miast i wsi jest najwyższa w następujących województwach: dolnośląskie (2000 zł), małopolskie (1400 zł), lubuskie (około 1100 zł), mazowieckie (1000 zł) oraz zachodniopomorskie $(960$ zł). Zatem w przypadku tych województw młodzi mieszkańcy miast odnoszący sukces zawodowy mają większą szansę na osiągnięcie zdecydowanie wyższych zarobków niż najlepiej zarabiający mieszkańcy wsi (tabela 2).

Wysokość wynagrodzenia nie zawsze jest dobrym wskaźnikiem jakości zatrudnienia, ponieważ nie uwzględnia ona ważnego czynnika, jakim jest czas poświęcony na pracę. Innymi słowy, nawet wysoko płatna praca nie będzie wysokiej jakości, jeśli zajmować będzie zbyt wiele czasu. Warto zatem poszerzyć przedstawione powyżej analizy o porównanie zarobków z intensywnością wykonywanych zadań. W tabeli 3 znajduje się zestawienie, w którym porównać można przeciętne wynagrodzenie za godzinę pracy $^{8}$, jakie uzyskują osoby młode mieszkające

W przypadku oceny jakości otoczenia zawodowego wykorzystano następujące pytanie: Zadowolenie z pracy można rozpatrywać pod kilkoma względami. Proszę powiedzieć, jak bardzo jest Pan/Pani zadowolony/zadowolona) bądź niezadowolony/niezadowolona z 1) możliwości awansu; 2) warunków wykonywania pracy; 3) możliwości rozwoju osobistego i szkoleń (skala 5-punktowa).

7 W miastach i na wsiach zarobki są istotnie różne (na korzyść miast) z wyjątkiem województw: opolskiego, śląskiego i świętokrzyskiego.

${ }^{8} \mathrm{~W}$ obliczeniach wzięto pod uwagę deklaracje badanego odnośnie do przeciętnej tygodniowej liczby godzin spędzonych w pracy, włącznie z nadgodzinami płatnymi oraz godzinami, za które badany nie uzyskał wynagrodzenia. 
w miastach i na wsiach. Nie są to duże różnice płac w obydwu grupach (chodzi tu o osoby mieszkające na wsi, a niekoniecznie pracujące na wsi) - przeciętna płaca otrzymywana za godzinę pracy jest wyższa wśród młodych mieszkańców miast zaledwie o około 1 zł. Warto ponadto dodać, że różnice w zarobkach zwiększają się wraz z przejściem do grup o wyższych wynagrodzeniach - wśród 5\% najlepiej zarabiających mieszkańców miast i wsi różnica najniższej ich płacy godzinowej zwiększa się do 4 zł. Różnica być może nie jest duża, jednak w skali miesiąca generuje już istotne zyski.

Tabela 2. Przeciętne miesięczne zarobki netto

\begin{tabular}{|l|c|c|}
\hline \multicolumn{1}{|c|}{ Wyszczególnienie } & Miasto & Wieś \\
\hline$N$ (liczba ważnych odpowiedzi) & 6645 & 4168 \\
\hline Średnia (w zł) & $1774,94^{\mathrm{a}}$ & $1575,26^{\mathrm{a}}$ \\
\hline Mediana (w zł) & 1600,00 & 1500,00 \\
\hline Dominanta (w zł) & 2000 & 2000 \\
\hline Odchylenie standardowe & 1445,218 & 1067,572 \\
\hline $\begin{array}{l}\text { Percentyle } \\
25\end{array}$ & 1000,00 & 980,29 \\
\hline 50 & 1600,00 & 1500,00 \\
\hline 75 & 2110,00 & 2000,00 \\
\hline
\end{tabular}

${ }^{a}$ różnica między średnimi, $p<0,001$.

Źródło: opracowanie własne na podstawie danych BKL 2010-2014.

Tabela 3. Wynagrodzenie za godzinę pracy badanego (kwota netto)

\begin{tabular}{|l|c|c|}
\hline \multicolumn{1}{|c|}{ Wyszczególnienie } & Miasto & Wieś \\
\hline$N$ (liczba ważnych odpowiedzi) & 4170 & 2635 \\
\hline Średnia (w zł) & $13,1324^{\mathrm{a}}$ & $11,3940^{\mathrm{a}}$ \\
\hline Mediana (w zł) & 10,6250 & 9,4369 \\
\hline Dominanta (w zł) & 12,50 & 12,50 \\
\hline $\begin{array}{l}\text { Percentyle } \\
25\end{array}$ & 8,3333 & 7,5000 \\
\hline 50 & 10,6250 & 9,4369 \\
\hline 75 & 14,3750 & 12,5000 \\
\hline 95 & 25,0000 & 21,2925 \\
\hline
\end{tabular}

a różnica między średnimi, $p<0,001$.

Źródło: opracowanie własne na podstawie danych BKL 2010-2014. 


\begin{tabular}{|c|c|c|c|c|c|c|c|c|c|c|c|c|c|c|c|c|c|c|}
\hline \multirow{2}{*}{$z$} & $\frac{0}{3}$ & 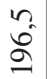 & $\tilde{y}$ & $\begin{array}{l}\infty \\
\tilde{n} \\
n\end{array}$ & $\frac{\infty}{\infty}$ & $\overrightarrow{0}$ & $\frac{n}{\hat{2}}$ & $\stackrel{m}{\stackrel{m}{\delta}}$ & $\frac{\sigma_{n}}{\vec{n}}$ & 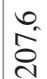 & $\hat{\AA}$ & 㔯 & $\begin{array}{l}0 \\
\stackrel{0}{\pi}\end{array}$ & $\begin{array}{l}n \\
2 \\
0\end{array}$ & $\frac{0}{a}$ & $\begin{array}{l}\infty \\
\text { dే } \\
\text { d }\end{array}$ & $\begin{array}{c}0 \\
\infty \\
\infty\end{array}$ & \\
\hline & 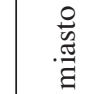 & $\begin{array}{l}0 \\
\text { I } \\
\text { mे }\end{array}$ & $\begin{array}{l}0 \\
\approx \\
0\end{array}$ & ชู & ป̂ & $\begin{array}{l}a \\
\grave{2}\end{array}$ & $\vec{\infty}$ & $\begin{array}{l}0 \\
\infty \\
0 \\
0\end{array}$ & $\begin{array}{l}\infty \\
0 \\
0\end{array}$ & פิ & $\underset{⿱ 乛}{g}$ & n & స్ & $\begin{array}{l}n \\
\text { aे }\end{array}$ & $\begin{array}{l}0 \\
\hat{\sigma} \\
\sigma\end{array}$ & ra & $\begin{array}{l}n \\
m \\
\tilde{n}\end{array}$ & \\
\hline \multirow{4}{*}{ 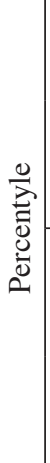 } & $\frac{4}{3}$ & $\overrightarrow{\tilde{N}}$ & $\frac{n}{2}$ & $\begin{array}{l}0 \\
\text { in }\end{array}$ & $\vec{i}$ & $\hat{\sigma}$ & 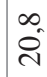 & $\stackrel{n}{=}$ & $\begin{array}{l}0 \\
\ddot{v}\end{array}$ & O̊. & $\stackrel{\circ}{\stackrel{i}{0}}$ & $\stackrel{0}{2}$ & $\begin{array}{l}\infty \\
\stackrel{+}{\sim}\end{array}$ & $\dot{\theta}_{\dot{n}}$ & ৯े & ㅇ. & $\stackrel{\sim}{d}$ & \\
\hline & 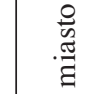 & $\begin{array}{l}\infty \\
\text { in }\end{array}$ & $\stackrel{m}{m}$ & $\stackrel{m}{\stackrel{n}{v}}$ & $\overrightarrow{\mathrm{n}}$ & $\begin{array}{l}n \\
\tilde{N}\end{array}$ & $\begin{array}{l}\circ \\
\end{array}$ & $\begin{array}{l}0 \\
\text { in }\end{array}$ & $\begin{array}{l}\vec{\sigma} \\
\infty \\
\sim\end{array}$ & in & $\frac{m}{m}$ & $\begin{array}{l}n \\
0 \\
0\end{array}$ & $\begin{array}{l}0 \\
\end{array}$ & $\begin{array}{l}0 \\
0 \\
0 \\
i\end{array}$ & O. & ন & $\begin{array}{l}0 \\
i \\
i j\end{array}$ & \\
\hline & $\frac{0}{3}$ & $\stackrel{n}{\sim}$ & $\tilde{6}$ & $\underset{r}{\nabla_{n}}$ & $\stackrel{n}{n}$ & $\stackrel{\infty}{\sim}$ & $\vec{\infty}$ & $\cong$ & $\begin{array}{c}0 \\
\infty\end{array}$ & 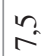 & $n$ & $\stackrel{0}{\circ}$ & $\infty$ & $n$ & $\approx$ & 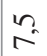 & $\stackrel{2}{\sim}$ & \\
\hline & 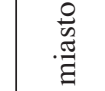 & $\vec{\infty}$ & $\approx$ & $\begin{array}{l}+ \\
\infty\end{array}$ & $\vec{\infty}$ & $\vec{\infty}$ & $\therefore$ & $\stackrel{0}{0}$ & 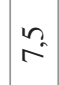 & $\stackrel{\infty}{\sim}$ & $\vec{\infty}$ & $\begin{array}{l}0 \\
\infty\end{array}$ & $\vec{\infty}$ & $\stackrel{\infty}{\sim}$ & $\infty$ & $\stackrel{n}{\sim}$ & $\begin{array}{l}3 \\
\infty\end{array}$ & \\
\hline \multirow{2}{*}{ 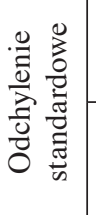 } & $\frac{w}{3}$ & $\vec{\therefore}$ & $\theta_{0}^{\circ}$ & ţ & in & 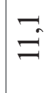 & $\stackrel{\infty}{0}$ & กี & ñ & $n$ & $\stackrel{\sigma_{-}}{=}$ & $\stackrel{m}{q}$ & a. & ?. & $\vec{r}$ & $\begin{array}{l}\nabla_{n} \\
\infty\end{array}$ & 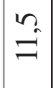 & \\
\hline & 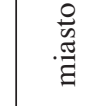 & $\vec{a}$ & $\overrightarrow{0}$ & $\begin{array}{l}\infty \\
n \\
\sim\end{array}$ & $\begin{array}{l}0 \\
\text { I }\end{array}$ & ㅇ. & ชู & $\stackrel{+}{\sim}$ & $\bar{\Xi}$ & O. & $\stackrel{+}{=}$ & $\stackrel{0}{r}$ & $\cong$ & $\begin{array}{l}\infty \\
\sigma_{0}\end{array}$ & $\bar{\infty}^{\circ}$ & $\stackrel{m}{\simeq}$ & 2 & \\
\hline \multicolumn{2}{|c|}{ 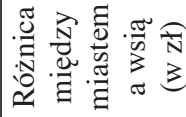 } & $\hat{\mathrm{i}}$ & $\tilde{i}$ & $\hat{i}$ & $\stackrel{n}{m}$ & $\overrightarrow{0}$ & $\stackrel{?}{-}$ & ले & $\tilde{n}$ & $\because$ & $\stackrel{\infty}{=}$ & $\hat{i}$ & $\tilde{0}$ & $\begin{array}{l}\hat{0} \\
0 \\
1\end{array}$ & i & $\because$ & $\stackrel{ \pm}{-}$ & $\vec{v}$ \\
\hline \multirow{2}{*}{ 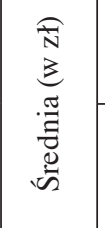 } & $\frac{4}{3}$ & $\cong$ & $\infty$ & $\begin{array}{l}\infty \\
0 \\
0\end{array}$ & $\hat{\varrho}$ & $\begin{array}{l}0 \\
\text { I }\end{array}$ & $\stackrel{0}{=}$ & $\hat{0}$ & $\stackrel{\infty}{=}$ & $\infty$ & $\stackrel{0}{=}$ & $\stackrel{n}{\varrho}$ & $\hat{\simeq}$ & $\vec{m}$ & $\stackrel{0}{=}$ & $\hat{0}$ & $\stackrel{m}{=}$ & \\
\hline & 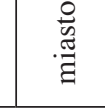 & $\stackrel{\sim}{\check{J}}$ & $\stackrel{\sigma_{i}}{\stackrel{c}{c}}$ & $\ddot{n}$ & 吉 & $\underline{\sigma}$ & $\stackrel{0}{\stackrel{0}{2}}$ & $\begin{array}{l}0 \\
\dot{ \pm}\end{array}$ & $\tilde{\simeq}$ & $\stackrel{m}{\simeq}$ & $\stackrel{\vec{\sigma}}{\stackrel{\sigma}{2}}$ & $\begin{array}{l}\infty \\
\stackrel{I}{I}\end{array}$ & $\infty$ & $\tilde{\simeq}$ & בे & $\stackrel{\text { בn }}{\simeq}$ & $\hat{\mathrm{a}}$ & \\
\hline \multicolumn{2}{|r|}{\begin{tabular}{l}
0 \\
\multirow{3}{*}{} \\
0 \\
0 \\
$\frac{0}{0}$ \\
$\frac{0}{3}$ \\
3
\end{tabular}} & $\begin{array}{l}\frac{0}{2} \\
\frac{2}{5} \\
\frac{w}{w 0} \\
0 \\
\vdots \\
0 \\
0\end{array}$ & 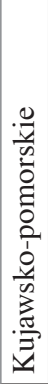 & 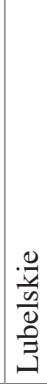 & 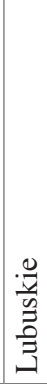 & 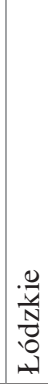 & $\begin{array}{l}\frac{0}{\frac{\pi}{v}} \\
\frac{0}{0} \\
0 \\
\frac{0}{0} \\
\frac{0}{\pi} \\
\frac{\pi}{2}\end{array}$ & 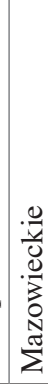 & $\begin{array}{l}\frac{0}{2} \\
\frac{\pi}{0} \\
0 \\
0 \\
0\end{array}$ & 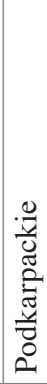 & 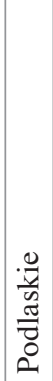 & $\begin{array}{c}\cdot \frac{y}{y} \\
\text { w } \\
\vdots \\
\vdots \\
0 \\
0\end{array}$ & 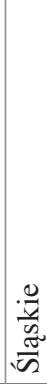 & 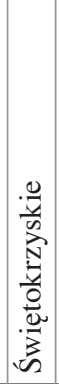 & 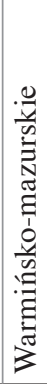 & $\begin{array}{l}\frac{0}{2} \\
\frac{0}{0} \\
0 \\
\frac{0}{0} \\
\frac{y}{0} \\
0 \\
3\end{array}$ & 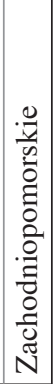 & 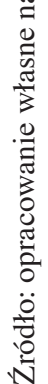 \\
\hline
\end{tabular}


Najbardziej interesujące okazują się różnice w poszczególnych regionach. Najwięcej zyskują mieszkańcy miast w województwach: mazowieckim, dolnośląskim, lubelskim, lubuskim i kujawsko-pomorskim. Są to regiony, w których znajdują się są silne ośrodki miejskie, a także wyraźnie odznaczające się ekonomicznie peryferia.

Jak wspomniano, nie obserwuje się dużych różnic w wycenie godziny pracy mieszkańców wsi i miast, uwzględniając wyłącznie grupę najmniej zarabiających, tj. dolny kwartyl (por. tabela 4). Im wyższe zarobki, tym różnice te są coraz większe i sięgają dla ostatniego kwartyla, w zależności od regionu, od kilku do kilkunastu złotych. Można zatem założyć, że największe różnice pomiędzy młodymi mieszkańcami miast i wsi nie łączą się z przeciętnymi zarobkami, ale z wyższą szansą na awans ekonomiczny, co może się wiązać z tym, że określony, wysoki poziom wyceny godziny pracy, występuje głównie w zawodach zazwyczaj wykonywanych w ośrodkach miejskich.

\section{Stabilność zatrudnienia i jakość otoczenia zawodowego}

Poczucie stabilności zatrudnienia jest jednym z najważniejszych wymiarów ogólnego zadowolenia z wykonywanej pracy [Holland i in. 2011, Stride, Wall i Catley 2007]. Zgodnie z wynikami badania CBOS aż 64\% badanych Polaków ocenia swoją pracę jako dającą pewność zatrudnienia i poczucie stabilizacji [Zadowolenie z pracy... 2013, s. 3]. Warto jednak zwrócić uwagę na czynniki, które potencjalnie mogą mieć wpływ na zadowolenie. Jednym z takich czynników jest właśnie miejsce zamieszkania.

Dane BKL potwierdzają ogólnie wysoki poziom zadowolenia młodych Polaków z pewności zatrudnienia, a także wskazują na istniejące w tym zakresie różnice regionalne. Przykładowo największa dysproporcja w odsetku zadowolonych w miastach w stosunku do analogicznego odsetka na wsiach (na korzyść miast) występuje w województwach świętokrzyskim, podkarpackim i mazowieckim, najmniejsza w lubelskim, lubuskim, pomorskim i wielkopolskim.

Ze stabilnością zawodową wiążą się także perspektywy na dalszy rozwój kariery zawodowej. Jak można zauważyć na rys. 2, ocena perspektyw na przyszłość jest odmienna w przypadku młodych ze wsi i młodych pochodzących z miast. Ci pierwsi zdecydowanie częściej przewidują zachowanie statusu (to samo miejsce i stanowisko pracy), natomiast mieszkańcy miast częściej prognozują awans zawodowy lub zmianę obecnego pracodawcy. Można zatem powiedzieć, że młodych z miast cechuje większa skłonność do mobilności zawodowej i wyższe aspiracje, co finalnie (w ogólnym rozrachunku) może działać na ich korzyść. 
Jak wspomniano, ocenę perspektyw zawodowych wiąże się z takim obszarem jak województwo. Największe w tym zakresie różnice między miastami a wsiami występują w województwach: wielkopolskim, małopolskim i kujawsko-pomorskim.

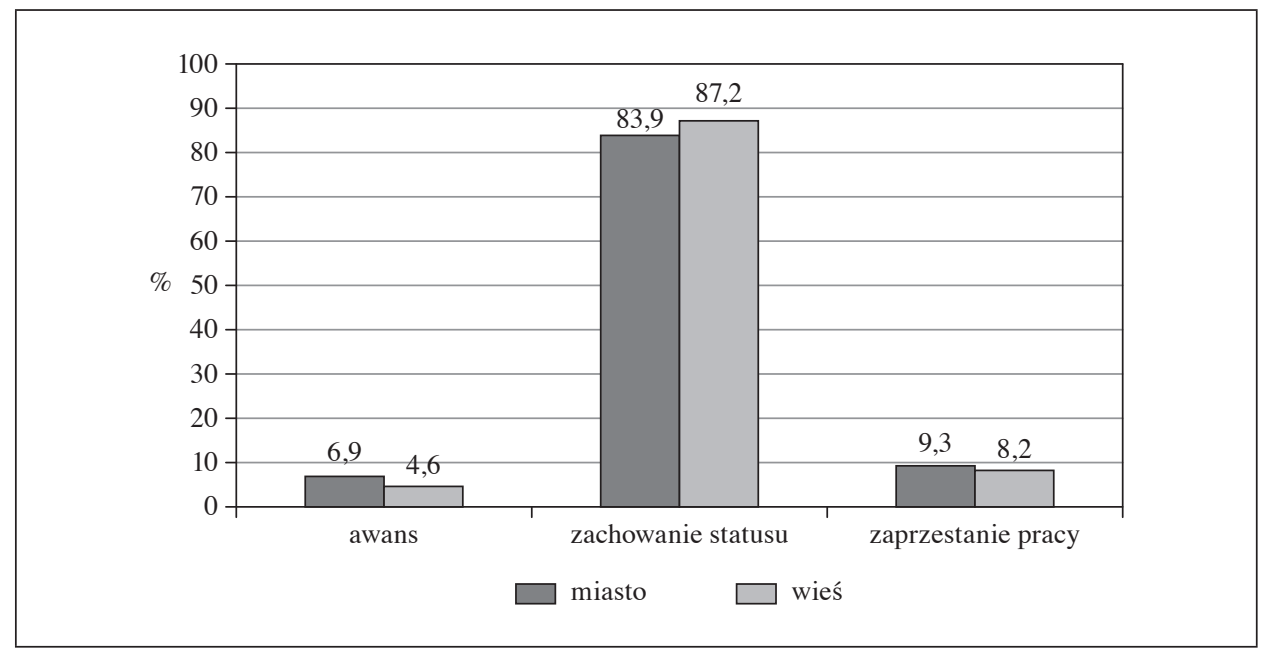

Rys. 2. Procent badanych mieszkańców miast i wsi spodziewających się: awansu, zachowania statusu zawodowego lub zaprzestania pracy (liczba ważnych odpowiedzi: miasto - 6067, wieś - 3603)

Źródło: opracowanie własne na podstawie danych BKL 2010-2014.

Mniejsze różnice widoczne są w przypadku oceny jakości otoczenia zawodowego przez pracowników pochodzących z miast i wsi - w podobny sposób oceniają oni warunki wykonywanej pracy. Zaledwie niewielką przewagę widać w opinii na temat możliwości rozwoju osobistego i szkoleń (niecały pkt proc. więcej zadowolonych wśród mieszkańców miast), a także możliwości awansu (niecałe 3 pkt proc. więcej zadowolonych wśród mieszkańców miast), choć przy kontroli dodatkowych zmiennych (w tym przede wszystkim poziomu wykształcenia) różnice te się pogłębiają (tabela 5).

Co ciekawe, oceny możliwości rozwoju osobistego nie są zbieżne z realnymi wskaźnikami uczestnictwa w szkoleniach i samokształceniu. W grupie młodych mieszkańców wsi jest widoczna zaniżona aktywność edukacyjna (71\% z nich w stosunku do 64,3\% mieszkańców miast - w ciągu ostatniego roku nie podnosiło kompetencji w żadnej formie) - rys. 3. Mieszkańcy miast zwracają także uwagę na odmienne niż u mieszkańców wsi czynniki utrudniające aktywność edukacyjną, tj. głównie zbyt wysoką cenę kursów/szkoleń oraz brak czasu z przyczyn zawodowych. 
Tabela 5. Ocena jakości otoczenia zawodowego przez młodych pracowników

\begin{tabular}{|l|c|c|c|c|c|c|}
\hline \multirow{2}{*}{ Wyszczególnienie } & \multicolumn{2}{|c|}{ Możliwość awansu } & \multicolumn{2}{c|}{$\begin{array}{c}\text { Warunki } \\
\text { wykonywanej pracy }\end{array}$} & \multicolumn{2}{c|}{$\begin{array}{c}\text { Możliwość rozwoju } \\
\text { osobistego i szkoleń }\end{array}$} \\
\cline { 2 - 7 } & miasto & wieś & miasto & wieś & miasto & wieś \\
\hline Niezadowolony (w \%) & 24,9 & 27,6 & 8,8 & 8,2 & 20,4 & 21,0 \\
\hline $\begin{array}{l}\text { Trudno powiedzieć } \\
\text { (w \%) }\end{array}$ & 29,1 & 29,2 & 11,5 & 11,6 & 21,2 & 21,7 \\
\hline Zadowolony (w \%) & 46,0 & 43,2 & 79,7 & 80,2 & 58,4 & 57,3 \\
\hline$N$ & 6065 & 3603 & 6065 & 3603 & 6064 & 3602 \\
\hline
\end{tabular}

Źródło: opracowanie własne na podstawie danych BKL 2010-2014.

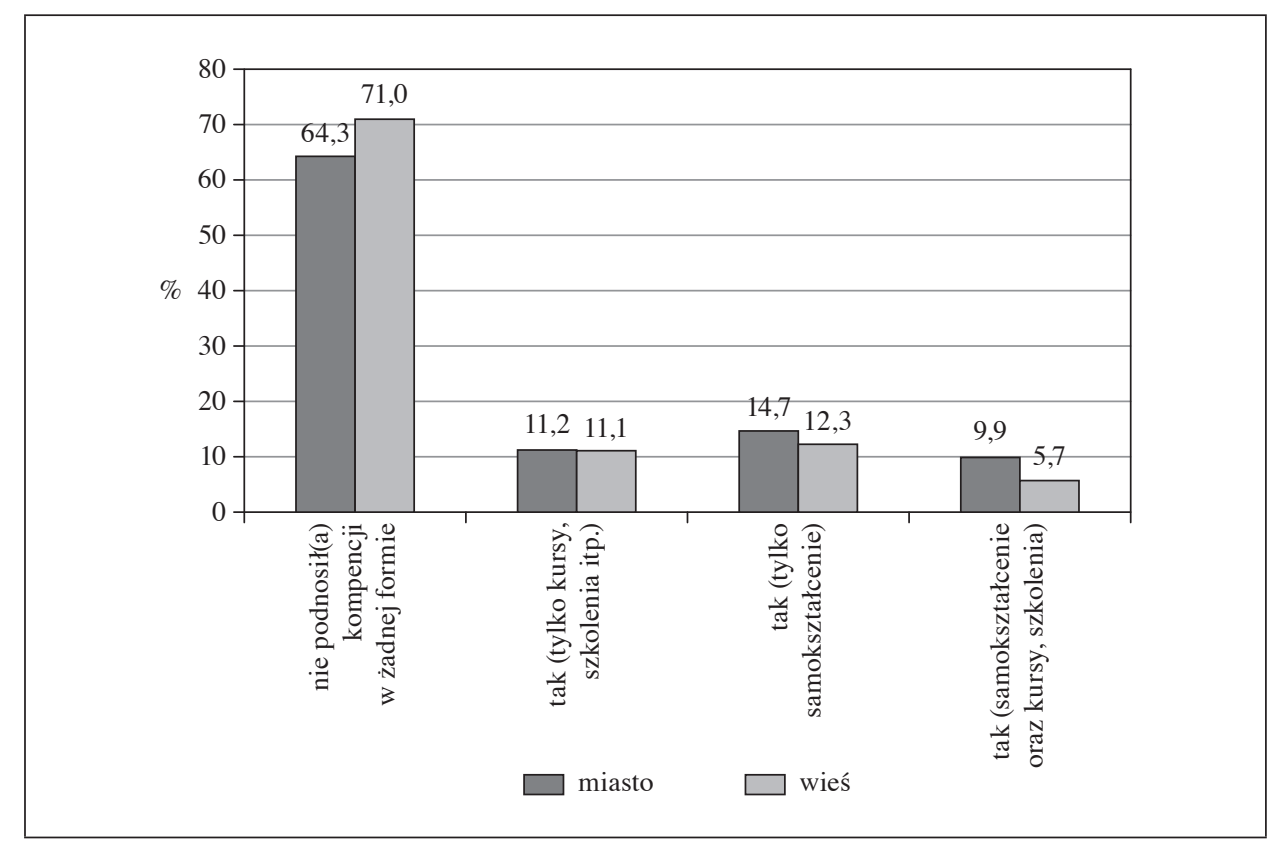

Rys. 3. Uczestnictwo w szkoleniach i samokształcenie w ostatnich 12 miesiącach (procent ważnych odpowiedzi; liczba ważnych odpowiedzi: miasto - 16190, wieś - 11060)

Źródło: opracowanie własne na podstawie danych BKL 2010-2014.

Młodzi mieszkańcy wsi jako powód zazwyczaj wymieniają brak interesujących kursów w pobliżu miejsca zamieszkania oraz brak potrzeby szkolenia się i przydatności takiego szkolenia w pracy zawodowej. Mieszkańcy miast częściej chętni byli dokształcać się sami, szczególnie w takich formach jak: korzystanie z książek i profesjonalnych magazynów, programów komputerowych i Internetu, jak również 
poprzez zwiedzanie wystaw, galerii i centrów nauki. Ponadto częściej planowali dokształcać się w przyszłości.

\section{Podsumowanie}

W artykule próbowano zweryfikować tezę o istotności różnicy pomiędzy mieszkańcami miast i wsi w zakresie szans na pracę wysokiej jakości (w wymiarze zarobków, stabilności zatrudnienia oraz jakości otoczenia zawodowego). Na podstawie danych empirycznych zaobserwowano niewielkie różnice między mieszkańcami miast i wsi, jednak perspektywy zawodowe młodych z miasta okazały się lepsze.

Znacznie częściej, czynnikiem różnicującym jakość zatrudnienia - szczególnie wśród ludzi młodych - jest nie tyle miejsce zamieszkania, ile miejsce wykonywania pracy. W tym przypadku coraz więcej młodych osób z obszarów wiejskich, nieposiadających własnych gospodarstw rolnych, decyduje się na pracę w okolicznych ośrodkach miejskich. Zatem im bliżej miasta i im lepiej dana miejscowość jest skomunikowana z ośrodkiem miejskim, tym różnice w jakości zatrudnienia między mieszkańcami miast i wsi będą się zacierać. Jest to element odróżniający pokolenie młodych mieszkańców wsi od ich rodziców, częściej zatrudnionych w rolnictwie, a także częściej wykonujących pracę w bliskiej okolicy miejsca zamieszkania.

Obserwowana nieco niższa jakość wykonywanej pracy zamieszkałych na wsiach młodych, nie wynika z ich niższego poziomu wykształcenia, choć wykształcenie jest tutaj czynnikiem, który w interesujący sposób moderuje tę zależność. Zadowolenie z jakości zatrudnienia wśród mieszkańców miast i wsi nieposiadających wyższego wykształcenia jest prawie takie samo. Różnice widoczne są w przypadku młodych osób z wykształceniem wyższym. Wśród młodych mieszkańców wsi, którzy ukończyli uczelnie, a następnie znaleźli zatrudnienie, obserwuje się istotnie niższe zadowolenie z wykonywanej pracy, a także niższą ocenę jej jakości.

Można określić wiele potencjalnych przyczyn opisanej zależności, jednak jedna z nich wydaje się najbardziej prawdopodobna. Jest nią znacznie częstszy wśród mieszkańców wsi nietrafny wybór edukacyjny, tj. wybór uczelni, kierunku lub formy studiów, które dają niższe stopy zwrotu z kształcenia [Białecki 1982, Szafraniec 2001, Świerzbowska-Kowalik 2000, Wasilewski 2009]. Potwierdzają to dane BKL dotyczące samoocen kompetencyjnych młodych mieszkańców miast i wsi (zob. tabela 6). 
Tabela 6. Autoocena posiadanych kompetencji

\begin{tabular}{|c|c|c|c|c|c|c|}
\hline \multirow[t]{2}{*}{ Wyszczególnienie } & \multicolumn{2}{|c|}{$N$} & \multicolumn{2}{|c|}{ Średnia ocena } & \multicolumn{2}{|c|}{$\begin{array}{l}\text { Odchylenie } \\
\text { standardowe }\end{array}$} \\
\hline & miasto & wieś & miasto & wieś & miasto & wieś \\
\hline \multicolumn{7}{|c|}{ Kompetencje - ogółem } \\
\hline $\begin{array}{l}\text { Wyszukiwanie i analiza informacji oraz } \\
\text { wyciąganie wniosków }\end{array}$ & 16194 & 11060 & 3,57 & 3,36 & 0,901 & 0,907 \\
\hline Obsługa, montowanie i naprawa urządzeń & 16194 & 11061 & 2,88 & 2,88 & 1,232 & 1,221 \\
\hline Wykonywanie obliczeń & 16195 & 11060 & 3,39 & 3,27 & 1,016 & 0,985 \\
\hline $\begin{array}{l}\text { Obsługa komputera i wykorzystanie Inter- } \\
\text { netu }\end{array}$ & 16191 & 11060 & 3,97 & 3,69 & 0,988 & 1,078 \\
\hline Zdolności artystyczne i twórcze & 16193 & 11061 & 2,88 & 2,66 & 1,169 & 1,138 \\
\hline Sprawność fizyczna & 16193 & 11061 & 3,86 & 3,93 & 0,928 & 0,920 \\
\hline $\begin{array}{l}\text { Samoorganizacja pracy i przejawianie inicja- } \\
\text { tywy, terminowość }\end{array}$ & 16192 & 11058 & 3,69 & 3,55 & 0,911 & 0,910 \\
\hline Kontakty z innymi ludźmi & 16194 & 11059 & 3,96 & 3,88 & 0,863 & 0,857 \\
\hline Organizowanie i prowadzenie prac biurowych & 16189 & 11059 & 3,20 & 2,91 & 1,129 & 1,164 \\
\hline $\begin{array}{l}\text { Umiejętność: zdolności kierownicze i orga- } \\
\text { nizacja pracy }\end{array}$ & 16190 & 11059 & 3,19 & 3,01 & 1,079 & 1,103 \\
\hline Umiejętność: dyspozycyjność & 16196 & 11060 & 3,78 & 3,71 & 0,975 & 1,005 \\
\hline $\begin{array}{l}\text { Biegłe posługiwanie się językiem polskim } \\
\text { (BKL 3-5) }\end{array}$ & 9684 & 6742 & 3,86 & 3,74 & 0,945 & 0,995 \\
\hline \multicolumn{7}{|c|}{ Kompetencje - szczegółowo } \\
\hline Szybkie streszczanie dużej ilości tekstu & 16196 & 11060 & 3,32 & 3,15 & 0,987 & 0,984 \\
\hline Logiczne myślenie, analiza faktów & 16196 & 11059 & 3,72 & 3,54 & 0,893 & 0,899 \\
\hline Ciągłe uczenie się nowych rzeczy & 16196 & 11060 & 3,83 & 3,70 & 0,867 & 0,885 \\
\hline Wykonywanie prostych rachunków & 16190 & 11059 & 3,74 & 3,60 & 0,989 & 1,001 \\
\hline $\begin{array}{l}\text { Wykonywanie zaawansowanych obliczeń } \\
\text { matematycznych }\end{array}$ & 16190 & 11059 & 2,78 & 2,61 & 1,186 & 1,143 \\
\hline $\begin{array}{l}\text { Podstawowa znajomość pakietu typu MS } \\
\text { Office }\end{array}$ & 16196 & 11061 & 3,67 & 3,30 & 1,151 & 1,249 \\
\hline $\begin{array}{l}\text { Znajomość specjalistycznych programów, } \\
\text { pisanie programów, stron www }\end{array}$ & 16195 & 11060 & 2,62 & 2,36 & 1,268 & 1,224 \\
\hline Wykorzystanie Internetu (BKL 1-2) & 6507 & 4318 & 4,04 & 3,60 & 1,040 & 1,207 \\
\hline Samodzielne podejmowanie decyzji & 16195 & 11059 & 3,79 & 3,68 & 0,874 & 0,884 \\
\hline Przedsiębiorczość i przejawianie inicjatywy & 16192 & 11056 & 3,55 & 3,42 & 0,927 & 0,935 \\
\hline Kreatywność & 16195 & 11059 & 3,66 & 3,47 & 0,922 & 0,932 \\
\hline Odporność na stres & 16192 & 11058 & 3,55 & 3,44 & 0,948 & 0,950 \\
\hline Terminowa realizacja zaplanowanych działań & 16192 & 11059 & 3,79 & 3,71 & 0,897 & 0,874 \\
\hline
\end{tabular}


cd. tabeli 6

\begin{tabular}{|l|c|c|c|c|c|c|}
\hline \multirow{2}{*}{ Wyszczególnienie } & \multicolumn{3}{|c|}{$N$} & \multicolumn{2}{c|}{ Średnia ocena } & \multicolumn{2}{c|}{$\begin{array}{c}\text { Odchylenie } \\
\text { standardowe }\end{array}$} \\
\cline { 2 - 9 } & miasto & wieś & miasto & wieś & miasto & wieś \\
\hline Współpraca w grupie & 16195 & 11059 & 3,99 & 3,93 & 0,835 & 0,830 \\
\hline $\begin{array}{l}\text { Łatwe nawiązywanie kontaktów ze współ- } \\
\text { pracownikami }\end{array}$ & 16196 & 11059 & 3,98 & 3,91 & 0,859 & 0,863 \\
\hline Umiejętność: bycie komunikatywnym & 16190 & 11060 & 3,95 & 3,85 & 0,847 & 0,866 \\
\hline Rozwiązywanie konfliktów pomiędzy ludźmi & 16193 & 11057 & 3,47 & 3,31 & 0,971 & 1,013 \\
\hline $\begin{array}{l}\text { Przydzielanie zadań innym pracownikom } \\
\text { (BKL 1-2) }\end{array}$ & 6506 & 4318 & 3,25 & 3,04 & 1,050 & 1,063 \\
\hline Koordynowanie pracy innych pracowników & 16192 & 11059 & 3,18 & 3,00 & 1,076 & 1,098 \\
\hline Dyscyplinowanie innych pracowników & 16192 & 11059 & 3,09 & 2,94 & 1,102 & 1,102 \\
\hline Częste wyjazdy & 16194 & 11058 & 3,39 & 3,36 & 1,158 & 1,168 \\
\hline Elastyczny czas pracy & 16192 & 11059 & 3,54 & 3,48 & 1,076 & 1,082 \\
\hline
\end{tabular}

Uwaga: kompetncje zostały ocenione na skali 5-punktowej (1 - poziom niski, 2 - podstawowy, 3 - średni, 4 - wysoki, 5 - bardzo wysoki).

Źródło: opracowanie własne na podstawie danych BKL 2010-2014.

Można zauważyć, że oprócz oceny sprawności fizycznej - pozostałe oceny są przeciętnie niższe wśród osób młodych mieszkających na wsiach. Szczególnie podkreślić należy różnice w samoocenie ważnych obecnie umiejętności poznawczych (wyszukiwanie i analiza informacji, wyciąganie wniosków) oraz kompetencji cyfrowych (obsługa komputera i wykorzystanie Internetu, np. podstawowa znajomość pakietu typu MS Office, wykorzystanie Internetu).

\section{Literatura}

Białecki I. [1982], Wybór szkoły a reprodukcja struktury społecznej, Ossolineum, Warszawa.

Dearden L., McIntosh S., Myck M., Vignoles A. [2002], The Returns to Academic and Vocational Qualifications in Britain, „Bulletin of Economic Research”, vol. 54, nr 3, https://doi.org/10.1111/1467-8586.00152.

Dearden L., Reed H., Van Reenen J. [2006], The Impact of Training on Productivity and Wages. Evidence from British Panel Data, „Oxford Bulletin of Economics and Statistics", vol. 68, nr 4, https://doi.org/10.1111/j.1468-0084.2006.00170.x.

Domański H., Fedorewicz M., Prokopek A., Przybysz D., Sitek M., Smulczyk M., Żółtak T. [2012], From School to Work: Individual and Institutional Determinants of Educational and Occupational Career Trajectories of Young Poles, „Ask. Research \& Methods", vol. 21, nr 1. 
Handbook on Measuring Quality of Employment. A Statistical Framework [2015], United Nations Economic Commission for Europe, UN, New York, Geneva.

Harmon C., Walker I. [2000], The Returns to the Quantity and Quality of Education: Evidence for Men in England and Wales, „Economica”, vol. 67, https://doi.org/10.1111/ 1468-0335.00193.

Holland P., Pyman A., Cooper B.K., Teicher J. [2011], Employee Voice and Job Satisfaction in Australia. The Centrality of Direct Voice, „Human Resource Management”, vol. 50, nr 1, https://doi.org/10.1002/hrm.20406.

Investment in Human Capital Through Post-Compulsory Education and Traning: Selected Efficiency and Equity Aspects [2002], OECD Working Paper No. 333, OECD Publishing, Paris.

Jakość życia pracownika w perspektywie work - live balance? [2013], red. D. Walczak-Duraj, „Humanizacja Pracy”, vol. 4(274).

Jelonek M., Kasparek K., Magierowski M. [2015], Młodzi na rynku pracy - pracownicy, przedsiębiorcy, bezrobotni. Na podstawie analizy kierunków kształcenia zrealizowanej w 2014 roku w ramach V edycji projektu Bilans Kapitału Ludzkiego w Polsce, PARP, Warszawa.

Jelonek M., Mazur B. [2014], Edukacja - Rynek pracy - Zatrudnienie, WUP, Kraków.

Jelonek M., Szklarczyk D. [2012], Oczekiwania pracodawców a pracownicy jutra, PARP, Warszawa.

Lauer C., Steiner V. [2000], Returns to Education in West Germany - An Empirical Assessment, Discussion Paper No. 00-04, ZEW, Mannheim.

Mincer J. [1974], Schooling, Experience and Earnings, Columbia University Press, New York-London.

Mlonek K. [2006], Bezrobocie [w:] Polityka społeczna, red. A. Kurzynowski, SGH, IGS, Warszawa.

Nurzyńska I., Poczta W. [2014], Polska wieś 2014. Raport o stanie wsi, Wydawnictwo Naukowe Scholar, Warszawa.

OECD Employment Outlook 2014 [2014], OECD Publishing, Paris, https://doi.org/10.1787/ empl_outlook-2014-en.

Olędzki M. [1981], Kształtowanie jakości pracy. Propozycja dialogu, IWZZ, Warszawa.

O'Leary N., Sloane P. [2011], The Wage Premium for University Education in Great Britain during a Decade of Change, ,The Manchester School”, vol. 79, nr 4, https://doi.org/ 10.1111/j.1467-9957.2010.02189.x.

Psacharopoulos G., Patrinos H. [2002], Returns to Investment in Education: A Further Update, World Bank Policy Research Working Paper 2881.

Stan i struktura rejestrowanego bezrobocia na wsi w 2015 roku [2015], Ministerstwo Pracy i Polityki Społecznej, Warszawa.

Stride C., Wall T.D., Catley N. [2007], Measures of Job Satisfactions, Organizational Commitment, Mental Health and Job-related Well-being: A Bench-marking Manual, John Wiley \& Sons, West Sussex.

Szafraniec K. [2001], Wartość wyksztatcenia na wsi-fakty, tendencje, konsekwencje [w:] Wieś i rolnictwo na przełomie wieków, red. I. Bukraby-Rylska, A. Rosner, IRWiR PAN, Warszawa.

Świerzbowska-Kowalik E. [2000], Wykształcenie środowisk rodzinnych i miejsce zamieszkania jako wyznaczniki szans na podjęcie studiów, „Nauka i Szkolnictwo Wyższe”, vol. 2(16). 
Wasilewski K. [2009], Dostępność studiów wyższych dla młodzieży wiejskiej [w:] Idee diagnozy - nadzieje. Szkoła polska a idee równości, red. A. Męczkowska-Christiansen, P. Mikiewicz, Wydawnictwo DSW, Wrocław.

Zadowolenie z pracy i jej oceny. Komunikat z badań [2013], CBOS, Warszawa.

\section{Youth in the Countryside and in the City - Job Quality and the Diversity of Employment Opportunities for Young People}

(Abstract)

The article examines the differences in the quality of employment available to young people living in rural areas and cities. It argues that the latter are more likely to not only have a job, but also one of high quality. In the article, job quality is characterised using the OECD's three dimensions: the level of remuneration, employment stability and the quality of the work environment. The survey data collected as part of Human Capital in Poland (BKL) was used to verify the assumptions. The study makes two main contributions to the literature. First, it shows that the greatest differences between urban and rural residents are associated with the superior opportunity urban dwellers have for economic advancement. Second, it identifies two key factors that moderate the relationship between place of residence and quality of employment: 1) the region (strong or weak urban centers) and 2) the level of education (higher or lower levels).

Keywords: quality of job, young people, career opportunities, city, countryside, labour market. 